\title{
Environmental commitment and green innovation reaching success new products of creative industry in Bali
}

\author{
I Gusti Agung Ketut Gede Suasana \\ Ni Wayan Ekawati \\ Department of Management \\ Udayana University, Indonesia
}

\section{Keywords}

Environmental commitment, Green innovation, Success of new product, Bali silver creative industry.

\begin{abstract}
Business activities that have been happening are able to help the people's economy, but also considered quite alarming, because it is considered to be responsible for environmental damage. This situation needs to be saved by implementing environmentally friendly business. Environmentally friendly should emerge from within each individual entrepreneur. The purpose of this study is to explain the effect of environmental commitment on green innovation and product success that can affect Bali's silver creative industry. The study was conducted on small industrial silver in Gianyar regency as many as 469 business units. This study uses individual samples as a unit of analysis of 120 respondents. The analysis technique is SEM base Analisis of Moment Structures (AMOS). The research findings show that the commitment to the environment has a positive and significant impact on the green innovations applied so far. This finding means that the more entrepreneurs have a high commitment to safeguard the environment, the more innovative it will be in implementing green innovations. Environmental commitment has a positive and significant impact on the success of new products. The more committed to maintaining the environment for the entrepreneur, the more able to achieve the success of new products produced. Green innovations have a positive and significant impact on the success of new products. The more innovative the more successful the new product will be. The direct effect of environmental commitment to the ongoing success of new products has a greater value than the indirect influence. Without green innovation indicates that environmental commitment is able to influence the achievement of new product success.
\end{abstract}

Corresponding author: Ni Wayan Ekawati

Email addresses for corresponding author: niwayanekawati@gmail.com

First submission received: $16^{\text {th }}$ September 2017

Revised submission received: $8^{\text {th }}$ November 2017

Accepted: $27^{\text {th }}$ December 2017

\section{Introduction}

Competitive advantage is the expectation of every entrepreneur, so that efforts must be made on an ongoing basis through changes or possible innovations, including green innovation. The green innovation of an entrepreneur with a commitment to preserve the environment indicated a competitive advantage (Ekawati, N.W; Kertiyasa, N.N; Giantari, G.A.K; and Sariyathi, N.K., 2017). The level of competitive advantage of a company requires a continuous innovation approach. Thus, the development of innovation strategies can play a role in achieving business performance. Innovation can be done by utilizing and developing organizational resources continuously in achieving organizational performance. Financial indicators as well as product and revenue gains are still superior to other indicators as the most common for product performance, although there are still many steps to measure the performance of new products (Paladino, 2007; Wong and Tong, 2012). Thus, corporate profits and income levels, generally still an indicator to assess the performance or success of new products. However, when attention is paid to the green approach considered in product development, the financial competitiveness of green products and environmental responsibility can also be used to measure product success.

Achievement of successful new products with the implementation of green innovation requires the support of all parties, in particular the organization's commitment to efforts to preserve the natural 
environment. The commitment requires the support of environmental management as an effective basis for entrepreneurial behavior (Keogh and Polonsky, 1998). Environmental management is an operational guide for organizations that implement green business. Lately, entrepreneurs have started to show sensitivity behavior in conducting business activities related to environmental issues (Volery, 2002).

Entrepreneurial in Bali also has begun to implement environmentally friendly business, one of which is a silver craft creative industry particularly those in the industry centers. Creative industry able to create competent human resources in the era of globalization, as well as the welfare of the people of Indonesia. Silver creative industries to operate in, is inseparable from the production process generated waste. Silver production waste which is not monitored properly can harm natural habitats. Waste silver contain chemicals that are quite harmful to the natural environment and living things. The importance of maintaining the consistency of the development of the silver industry in increasing the export, it is necessary to design a development strategy in order to win the competition, both in the national and international arena. Industrial strategies that care for the environment through green innovation require high commitment from entrepreneurs to be entrepreneurs environmentally friendly.

\section{Theoretical Framework and Literature Review}

The commitment to protect the environment is very important for entrepreneurs in implementing green business. Environmental commitment shows the image of business as an effort to participate in preserving the natural environment. Keogh and Polonsky (1998) argue that commitment to the environment can be a very effective basis of entrepreneurial behavior that concerns the environment. Entrepreneurial behavior has a high commitment to the environment, is able to create organizational sustainability and environmental sustainability. Commitment to the environment shows the company's identity in organizational management that is always accompanied by efforts to preserve the natural environment (Ottman, 1992). Henriques and Sadorsky (1999) stated that the company's environmental profile consists of four criteria, namely; reactive, defensive, accommodative and proactive. Proactive organizations are usually more committed to safeguarding the environment.

Green innovation emphasizes more on innovation that does not harm the environment. Basically, green innovation is part of the innovation process and what sets it apart is its primary consideration. Green innovation considers the outcome of new ideas, their impact on the environment. Thus, green innovation is expected to produce products that are environmentally friendly, not only for the survival of the product but also for environmental sustainability. Green innovation is divided into two types, namely proactive and reactive green innovation (Chen, Y. S; Chang, H. Ching; and Feng, S.W., 2012). Proactive green innovation is an innovation on the environment that is actively carried out through its own initiative by creating new things to face competition, reduce costs, seize opportunities, lead markets, and gain competitive advantage. Meanwhile, reactive green innovation is a passive environmental innovation, just to comply with existing regulations, adjust to the demands of stockholders, simply react to environmental changes, and to face competitors' challenges.

Green innovation can be categorized into green product innovation and process (Wong, 2012). Green product innovation refers to the application of innovative ideas that lead to the design, manufacture and marketing of new green products that significantly outperform conventional competing products (Wagner, 2012). Governments and other institutions including NGOs, both national and international, have sought to set green product standards through agreements, regulations, practices, and guidance. Green process innovation is the application of innovative ideas that lead to the adoption of production processes that can reduce negative impacts on the ecological environment, human health, social, cultural and economic impacts (Chen, 2011). The process of green innovation is a process or activity that has criteria in accordance with industry and social contexts, which intend to serve, use and full consideration in the use of energy and resources, as well as the ecological impacts and sustainability issues in the manufacturing process (Chiou, T.Y; Chan, H.K; Lettice, F; and Chung, S.H., 2011).

Companies should always strive to develop their products according to the tastes and desires of consumers so as to continue to compete with other companies. Successful product development efforts will reward the company's risks, so companies must minimize the risk of product failure by implementing stages of product development in earnest (Paladino, 2007). The success of the resulting product will also 
be seen in the increase in income and the profit generated (Ekawati et al., 2017).

\section{Methodology}

This research uses quantitative research design using AMOS-based structural equation model (Creswell, J. W; Klassen, A. C; Clark, V. L. P and Smith, K. C, 2011). The location of the research was conducted in Bali in the silver handicraft creative industry as one of the Bali SMEs that produce local wisdom products. Research respondents are small business owners of silver handicrafts in Gianyar regency, because this industry is one of the biggest mainstays of supporting export value in Bali Province. The units of analysis were 120 respondents. The questionnaire is a data collection technique using a preprepared list of statements related to the variables studied (Sekaran, 2011). In-depth interviews are conducted in an unstructured, flexible manner in an informal setting, and are repeated.

\section{Research Variables}

The variables in this study are as follows: Exogenous variable is environmental commitment (X1). The environmental commitment (X1) consists of four measurement indicators, namely; has an environmental safeguard plan (X1.1), communicates environmental commitment (X1.2), has budget (X1.3), and implementation continuity (X1.4). All indicators are adopted and developed from the research of Henriques and Sadorsky (1999). Endogenous variables are as follows: Green innovation (Y1) consists of; product innovation (Y1.1) and process innovation (Y1.2). Product innovation (Y1.1), consists of five measurement indicators, namely; product design (Y1.1.1), product quality (Y1.1.2), and the use of recycled (Y1.1.3). Process innovation (Y1.2), consists of indicators of electricity-efficient production processes (Y1.2.1), water-efficient production processes (Y1.2.2) and production processes reduce waste (Y1.2.3). The indicator was developed from Wong (2012). The success of new products (Y2), consists of three measurement indicators, namely; superior product quality (Y2.1), unique product design (Y2.2), and able to generate better revenue (Y2.3). All these indicators are developed from Chang (2012). The conceptual framework in this study can be described as follows:

Figure. Framework Research Concepts

\section{Findings \& Discussion}

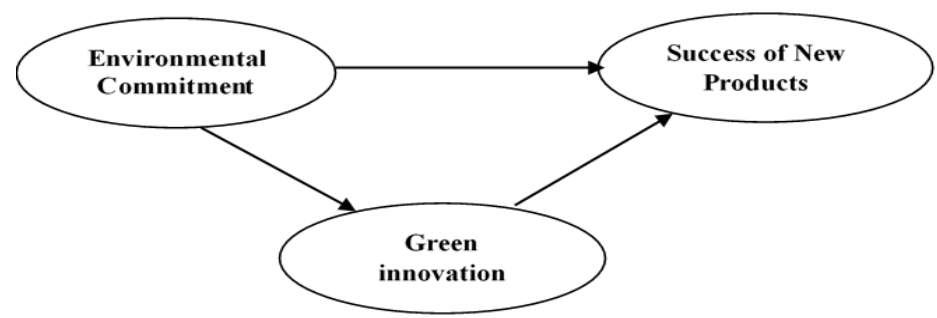

Analysis of direct effect, indirect effect, and total effect used to determine the strength of influence between the constructs, direct, indirect, and total effect. The results of the analysis on the direct effects, indirect effects, and total effects of each of the variables studied are as in the table.

Table. Direct Effect, Indirect Effect, and Total Effect Model the Effect of Environmental Commitment on New Product Success with Green Innovation as Mediation variable

\begin{tabular}{lcc}
\hline & & Standardized \\
Type Effect & Construct & Estimates \\
\hline
\end{tabular}

$\begin{array}{llr}\text { Direct effect } & \text { Environmental Commitment } \rightarrow \text { Green Innovation } & 0,641 \\ & \text { Environmental Commitment } \rightarrow \text { Success of New Products } & 0,438 \\ \text { Green Innovation } \rightarrow \text { Success of New Products } & 0,373 \\ \text { Indirect effect } & \text { Environmental Commitment } \rightarrow \text { Success of New Products } & 0,239 \\ & & 0,677\end{array}$




\section{The effect of environmental commitment to green innovation}

The test result for hypothesis 1 shows the value of path coefficient (standardized direct effect) of 0.641. Furthermore, the value of $\mathrm{P}$ obtained on the relationship of environment commitment variable (X1) to green innovation (Y1) is 0.000 . This can be interpreted that the environmental commitment has a positive and significant impact on green innovation. The higher the commitment of entrepreneurs in the effort to keep the environment in business activities, the better the application of green innovation that can be applied to the silver creative industry in Bali.

\section{The effect of environmental commitment to the success of new products}

The value of the path coefficient (standardized direct effect) obtained from the influence of environmental commitment to the success of new products amounted to 0.438 . Furthermore, the P-value obtained on the relationship of environment commitment variable (X1) to the success of new product (Y2) is 0,000 . This can be interpreted that the environmental commitment has a positive and significant impact on the success of new products. The higher the commitment of entrepreneurs in the effort to keep the environment in business activities, the more successful new products are produced in the silver creative industry in Bali. Successful new products can be measured by three indicators of superior product quality, unique product design, and the ability to generate better revenue. The results of the study found that the benefits that may be obtained are social benefits in the form of benefits that can be felt by the entire community, economic benefits such as economic welfare, and benefits of sustainability including maintaining the biological safety that is on earth. These benefits are able to attract entrepreneurial attention and begin to realize that it becomes a demand in the organization. This awareness emerged among the leaders of the company to create a green approach to organizational activity and environmental awareness efforts.

\section{The effect of green innovation on new product success}

The coefficient of the path (standardized direct effect) obtained from the influence of green innovation on the success of new products amounted to 0.438 . P-value obtained on the relationship of environment commitment variable (X1) to the success of new product (Y2) is 0.001 . This can be interpreted that green innovation has a positive and significant impact on the success of new products. The more innovative an entrepreneur in an effort to keep the environment in business activities, the more successful new products produced in the silver creative industry in Bali. Products produced with a green innovation approach can increase the profitability of the company, bring in new customers and increase revenue (Kash and Rycoft, 2000; Nassimbeni, 2003; and Chiou et al., 2011).

\section{The role of green innovation mediates the relationship between environmental commitments to successful new products}

The direct effect of environmental commitment to the success of new products amounted to 0.438 more than the indirect effect of the relationship between environmental commitments to the success of new products that is equal to 0.239 . This means that the commitment of the environment directly affects the success of new products without going through green innovation. The higher the commitment to the company's environments, the more successful the new product will be. This condition indicates the success of new products is not influenced by the existence of applied green innovation. Thus, without any green innovation implemented then the environmental commitment will be able to achieve the success of new products produced.

\section{Conclusions}

Entrepreneurial activities that are committed to the environment, green innovation, and success of new products in silver handicraft creative industries in Bali can be concluded that the commitment to the environment has a positive and significant impact on the green innovations applied so far. This means that the more entrepreneurs have a high commitment to safeguard the environment, the more innovative they will be in implementing green innovations. Environmental commitment has a positive and significant impact on the success of new products. The more committed to maintaining the environment for the entrepreneur, the more able to achieve the success of new products produced. Green innovations 
have a positive and significant impact on the success of new products. The more innovative the more successful the new product will be. The direct effect of environmental commitment to the success of new products has a greater value than indirect effect. Without green innovation indicates that environmental commitment is able to influence the achievement of new product success.

Attempts to support these activities require sufficient budgets to carry out a high commitment to safeguard the environment in business. Always maintain the quality of products that are environmentally friendly products. Make a green innovation with more efficient in the use of electricity. Keeping the new product generated in accordance with the direction of environmental maintenance and in accordance with the rules for saving the environment. The government is expected to pay more attention to organizations that implement green business, as it supports the sustainability of the organization and the sustainability of the natural environment and realizes Bali as a green provincial.

\section{References}

Chang, H-C. (2011). The Influence of corporate environmental ethics on competitive advantage: The mediation role of green innovation. Journal of Business Ethics, 104 (3): 361-370.

Chen Y.S., Chang Hsun-Ching, Feng Shang-Wu. (2012). Origins of green innovations: the differences between proactive and reactive green innovations. Journal of Management Decision, 50 (3):368-398

Chen, Y.S. (2011). Green organizational identity: sources and consequence. Management decision, 49 (3):384-404.

Chiou, T.Y., Chan, H.K., Lettice, F. and Chung, S.H. (2011). The influence of greening the suppliers and green innovation on environmental performance and competitive advantage in Taiwan. Transportation Research. Part E, 47 (6):822-36.

Creswell, J. W.; Klassen, A. C., Clark, V. L. P., and Smith, K. C., (2011). Best Practices for Mixed Methods Research in the Health Sciences. Bethesda: National Institutes of Health (NIH).

Ekawati, N.W., Kertiyasa, N.N., Giantari, I.G.A., Sariyathi, N.K. (2017). Ecopreneurship and Green Innovation for the Success of New Spa Products. Journal of Business and Retail Management Research (JBRMR), 11(3):13-24.

Henriques, I.P. and Sadorsky. (1999). The relationship between environmental ommitment and managerial perceptions of stakeholder importance. Academy of Management Journal, 42 (1): 87-99.

Kash, D.E. and Rycoft, R.W. (2000). Patterns of innovating complex technologies: a framework for adaptive network strategies. Research Policy, 29:819-31.

Keogh, P. and Polonsky, M. (1998). Environmental commitment: a basis for environmental entrepreneurship? Journal of Organizational Change Management, 11 (1):38-49.

Nassimbeni, G. (2003). Local manufacturing systems and global economy: are they compatible? The case of the Italian eyewear district. Journal of Operations Management, 21 (2):151-171.

Organization for Economic Corporation and Development. (2009). OECD annual report. Public Affairs Division, Public Affairs Communication Directorate.

Ottman, J.A. (1992). Green Marketing Challenges and Opportunities for the New Marketing Age, Chicago, IL: NTC Business Books.

Paladino, A. (2007). Investigating the drivers of innovation and new product success: a comparison of strategic orientations. Journal of Product Innovation Management, 24 (6):534-553.

Sekaran, Uma. (2011). Research Method fo Business, Metode Penelitian untuk Bisnis, Jakarta: Salemba Empat.

Volery, Thierry. (2002). Ecopreneurship: Rationale, current issues and futures challenges.

Publication of Swiss Research Institute of Small Business and Entrepreneurship. University of St. Gallen

Wagner, M. (2012). Entrepreneurship, Innovation and Sustainability, Greenleaf Publishing.

Wong, (2012). The influence of green product competitiveness on the success of green product innovation Empirical evidence from the Chinese electrical and electronics industry. European Journal of Innovation Management, 15 (4):468-490.

Wong, S.K.S. and Tong, C. (2012). The influence of market orientation on new product success. European Journal of Innovation Management, 15 (1):99-121. 